\title{
sciendo
}

CIVIL AND ENVIRONMENTAL ENGINEERING REPORTS

E-ISSN 2450-8594

CEER 2019; 29 (1): 001-017

DOI: $10.2478 /$ ceer-2019-0001

Original Research Article

\section{EXERGETIC DIAGNOSTICS OF A GAS-AND-STEAM POWER PLANT}

\author{
Wojciech STANEK ${ }^{1}$, Tomasz SIMLA \\ Silesian University of Technology, Gliwice, Poland
}

\begin{abstract}
Evaluation of thermodynamic efficiency of a power plant is usually performed using the method of so-called thermal diagnostics, based on energy balancing. Energetic analysis is however suitable only for a quantitative assessment and for comparing similar technologies. In order to properly assess the origins of energy losses in the given system, an exergetic analysis has to be applied. The paper describes the rules of exergetic diagnostics, which greatly extends the potential of classic thermal diagnostics. A calculation example of a combined cycle power plant is included. The example demonstrates the potential of exergetic diagnostics for locating exergy losses and explains the reasons for increased consumption of fuels by comparing two working conditions of the system: reference and operational.
\end{abstract}

Keywords: combined cycle power plant, exergetic analysis, mathematical model

\section{INTRODUCTION}

Diagnostics, in a general way, is defined [1] as a field dealing with recognition of the investigated system and definition of its present state and effects of planned development or improvement (e.g. changes through operational or design parameters). Diagnostics of industrial processes, including energy systems, is a part of technical diagnostics and its aim is the detection of reasons of changes in the state of the investigated system during its operation [2,3]. The state of the

${ }^{1}$ Corresponding author: Silesian University of Technology, Institute of Thermal Technology, Konarskiego s 22, 44-100 Gliwice, Poland, e-mail: wojciech.stanek@polsl.pl, tel. +48322371124 
system is defined by a set of values characterizing the system. Within the technical diagnostics most often two working conditions - reference state (often corresponding to the nominal operational parameters) and operational state are taken into account.

Thermal diagnostics with several practical examples of its applications has been presented in details in [2]. Within this work, the fundamentals of exergy diagnostics, which significantly increases the potential of thermal diagnostics, are presented and discussed. Exergy diagnostics is a technique from the field of advanced exergy analysis, which allows for the detailed detection of reasons for generation of exergy losses deciding of total thermodynamic perfection of the system. Procedures of exergy diagnostics [4], with application of mathematical modeling tools, allow for a detailed control of production processes and systems, simultaneously eliminating some constrains of analyses based only on $1^{\text {st }}$ law of thermodynamics, such as the lack of inclusion of quality of different energy carriers. Exergy diagnostics methods show also the interactions between components of the system and the actual locations of losses generation, which is not possible to determine using only energy balances. The described methods also allow to examine in detail the impact of changes in the operating parameters of the system on direct and induced exergy losses, as well as the effect of partitive exergy losses in specific components on changes in the demand for drive factors in the system. Summing up, it should be stated that exergy diagnostics locates and explains the reasons for the increased consumption of resources supplied to the system by comparing two working conditions: reference and any operational state of the system. The presented methods used in the field of exergy diagnostics will be discussed on the examples of a simplified and real scheme of a combined cycle gas turbine power plant.

\section{DEFINITION OF A PROBLEM OF EXERGY DIAGNOSTICS}

Within the exergy diagnostics procedure, the investigated system is evaluated from the point of view of the influence of operational parameters on the efficiency of the system, including a detailed detection of reasons for changes in the flows of energy driving the system. Additionally, the aim of analysis is to detect the actual locations and reasons responsible for these changes. For the exergy diagnostics two sets of operational parameters $x$ have to be known:

- for reference state $\mathbf{x}_{0}=\left[x_{0,1}, x_{0,2}, \ldots, x_{0, n}\right] \mathrm{x}_{0}=$

$\left[\mathrm{x}_{0,1}, \mathrm{x}_{0,2}, \ldots, \mathrm{x}_{0, \mathrm{n}}\right] \mathrm{x}_{0}=\left[\mathrm{x}_{0,1}, \mathrm{x}_{0,2}, \ldots, \mathrm{x}_{0, \mathrm{n}}\right]$,

- for operational state $\mathbf{x}_{1}=\left[x_{1,1}, x_{1,2}, \ldots, x_{1, n}\right]$.

Changes of the operational parameters first of all influence the exergy efficiency of particular components of the system. The final effect of these changes is the 
change of requirement for external resources entering the balance boundary of the system:

$$
\mathbf{x}_{0} \rightarrow \mathbf{x}_{1}=F_{T}\left(\mathbf{x}_{0}\right) \rightarrow F_{T}\left(\mathbf{x}_{1}\right)
$$

$F_{T} \quad$ total amount of exergy of resources (fuels) delivered to the analysed system,

$\mathrm{x}_{1} \quad$ actual operational parameters,

$\mathrm{x}_{0} \quad$ reference operational parameters.

Increased fuel exergy consumption $\Delta F_{T}$, known in thermo-economy literature [5$10]$ as fuel impact, can be defined as the difference of fuel exergy consumption between actual operational state and the reference state [4]:

$$
\Delta F_{T}=F_{T}\left(\mathrm{x}_{1}\right)-F_{T}\left(\mathrm{x}_{0}\right)
$$

Increase in consumption of fuel exergy delivered to the balance boundary can, in general, result from two reasons:

- increase of system production $\Delta P_{T}$,

- increase of exergy losses in components of the system $\Delta I$.

Fuel impact given by formula (2.2) can be therefore presented as:

$$
\Delta F_{T}=\Delta P_{T}+\sum_{j=1}^{n} \Delta I_{j}
$$

If the analyzed system is considered under constant production $\left(\Delta P_{T}=0\right)$, the fuel impact results only from irreversibilities and exergy losses in all components of the analysed system:

$$
\Delta F_{T}=\sum_{j=1}^{n} \Delta I_{j}
$$

and when reference $\left(\mathbf{x}_{\mathbf{0}}\right)$ and operational $\left(\mathbf{x}_{\mathbf{1}}\right)$ states are taken into account in the exergy diagnostics procedure, Eq. (2.3) takes the form:

$$
\Delta F_{T}=\sum_{j=1}^{n}\left[I_{j}\left(\mathbf{x}_{\mathbf{1}}\right)-I_{j}\left(\mathbf{x}_{\mathbf{0}}\right)\right]
$$

Changes of exergy losses in any $j$-th component of the system can be a direct result of a deterioration of performance of the considered $j$-th component. They can also be induced by other components of the system $i \neq j$ because of decreased efficiency of these components. The first of mentioned reasons will be classified as direct or intrinsic cause of changes in exergy losses, the second as induced or 
extrinsic cause. In the presented work, symbols accepted in thermo-economic literature $[5,6]$ have been applied:

- $\quad(\mathrm{MF})_{i}$ - direct (intrinsic) exergy losses (malfunction),

- $\quad(\mathrm{DF})_{i}$ - induced (extrinsic) exergy losses (disfunction).

In the case of direct reasons for increased exergy consumption, the deterioration of operation of the considered component due to changes in operating parameters $\mathbf{x}_{0} \rightarrow \mathbf{x}_{1}$ leads directly to increase of specific consumption of exergy in $i$-th component $\Delta \kappa_{j-i}$, which is produced in other $j$-th component of the system:

$$
\Delta \kappa_{j-i}=\kappa_{j-i}\left(\mathbf{x}_{1}\right)-\kappa_{j-i}\left(\mathbf{x}_{\mathbf{0}}\right)
$$

Index $\kappa_{j-i}$ can be defined as:

$$
\kappa_{j-i}=\frac{\dot{B}_{j-i}}{\dot{B}_{P, i}}
$$

$\dot{B}_{j-i} \quad$ part of total exergy driving the $i$-th component and generated in $j$-th

$\dot{B}_{P, i} \quad$ exergy of useful product generated in $i$-th component.

Determination of unitary partitive exergy consumption indices (defined by Eq. 2.7) is one of the fundamental steps in the procedure of exergy diagnostics. These indices are determined basing on the fuel-product table F-P. In this approach, fuel $F$ represents exergy driving the component, and product $P$ represents useful exergy generated in the component or system. One possible way to determine the F-P table is the application of matrix algorithm that will be presented and discussed in next part of the paper. The influence of changes of operational parameters $\mathbf{x}_{0} \rightarrow \mathbf{x}_{1}$ on the indices of specific exergy consumption $\kappa_{j-i}$ can be assessed using real operational data from measurement system of investigated plant [2]. Another solution is to apply a mathematical model [11-14].

Part of fuel impact $\Delta F_{T}$ defined by Eq. 2.5 representing direct exergy losses is named in thermo-economical analysis literature as malfunction [4-6,8-10]. Partitive malfunction $\Delta(M F)_{j-i}$ expressing the increase of exergy losss in $i$-th component, leading finally to the increase of consumption of products generated in other $j$-th component of the system $\Delta \kappa_{j-i}$, with constant production in considered component $P_{i}\left(\mathbf{x}_{\mathbf{0}}\right)$, is defined as [4,5,9]:

$$
\Delta(M F)_{j-i}=\Delta \kappa_{j-i} \cdot P_{i}\left(\mathbf{x}_{\mathbf{0}}\right)
$$

$P_{i} \quad$ exergy if product of $i$-th component. 
Total malfunction in $i$-th component $\Delta(M F)_{i}$ is equal to the sum of partitive malfunctions $\Delta(M F)_{j-i}$ taking into account all flows of input exergy to $i$-th component:

$$
\Delta(M F)_{i}=\sum_{j=0}^{m} \Delta \kappa_{j-i} \cdot P_{i}\left(\mathbf{x}_{\mathbf{0}}\right)
$$

$m \quad$ number of input flows to $i$-th component of analysed system.

The idea of malfunction is presented in Fig. 1.

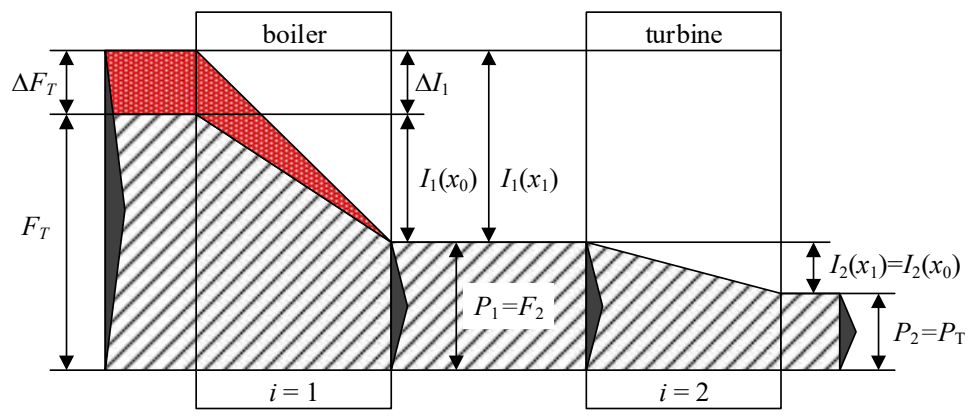

Fig. 1. Idea of direct exergy losses - malfunction $(M F)$

Induced exergy losses result from the fact that decrease of system component(s) performance and efficiency leads to the increase of production in other components of the system. It should be taken into account that all real components of the system are characterised by irreversible operation, always leading to exergy destruction. So induction of increased production $\Delta P$ always leads to the generation of additional exergy losses. This increased demand for exergy is cumulating in the system and finally leads to the increased demand for resources supplying the system (disfunction). The idea of induced exergy losses disfunction $(D F)$ is presented in Fig. 2.

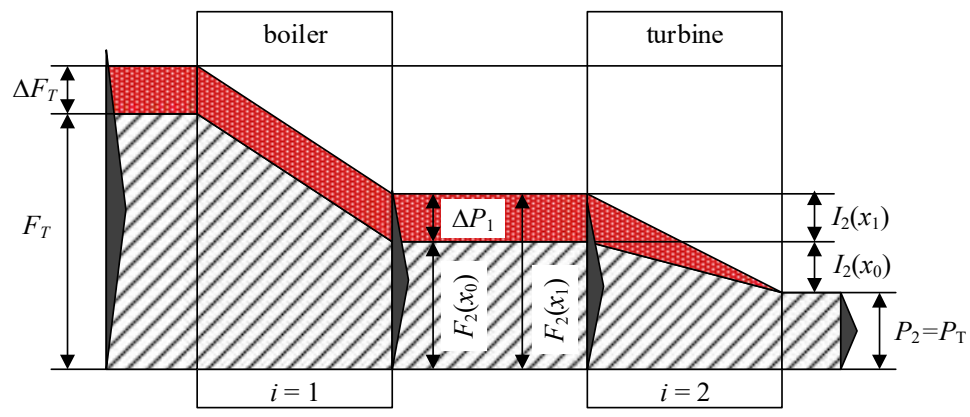

Fig. 2. Idea of induced exergy losses - disfunction $(D F)$ 
Taking into account local exergetic cost $k_{i}$ equal to unitary exergy consumption in $i$-th component:

$$
k_{i}=\frac{F_{i}}{P_{i}}
$$

minimal theoretical consumption of exergy of resources in $i$-th component would appear in the case of local unitary exergy cost $k_{i}=1$. Surplus of $k_{i}$ over $1\left(k_{i}-1\right)$ is the result of irreversibility burdening the $i$-th considered process. Increase of exergy production $\Delta P_{i}=P_{i}\left(\mathrm{x}_{1}\right)-P_{i}\left(\mathrm{x}_{0}\right)$ in $i$-th component is the result of increased demand for exergy in an other component of the system because of its decreased exergy efficiency. In other words, decreased exergy efficiency in $i$-th component induces the increase of production in other components, which is connected with increase of exergy losses in these components. Thus, disfunction can be expressed as [4-6,8-10]:

$$
(D F)_{i}=\left(k_{i}-1\right) \cdot \Delta P_{i}
$$

$k_{i} \quad$ unit local exergy cost for operational state $\mathrm{x}_{1}$ of component $i$.

Total exergy losses in $i$-th component encompassing both direct and induced exergy losses can be expressed as:

$$
\Delta I_{i}=(M F)_{i}+\sum_{j=1}^{n}(D F)_{j i} \quad i=1 ; \ldots ; n
$$

Thus, fuel impact expressed by means of malfunction and disfunction can be calculated as:

$$
\Delta F_{T}=\sum_{i=1}^{n} \Delta I_{i}=\sum_{i=1}^{n}\left[(M F)_{i}+\sum_{j=1}^{n}(D F)_{j i}\right]
$$

Unitary exergy cost of $j$-th product $k_{P j}^{*}$ can be expressed using irreversibility indices $\phi_{i, j}$ from the following formula [8-10]:

$$
k_{P j}^{*}=1+\sum_{i=1}^{n} \phi_{i, j}
$$

Coefficients $\phi_{i, j}$ express the share of $i$-th component in generation of exergy losses and generation of exergy cost $k_{P j}^{*}$ of $j$-th component's useful product. Coefficients $\phi_{i, j}$ are elements of irreversibility matrix I. Algorithm for determination of matrix $\boldsymbol{I}$ is explained in point 3.1. 


\section{ALGORITHM OF EXERGY DIAGNOSTICS}

The aim of procedure of exergy diagnostics is the assessment of influence of operational parameters changes $\mathbf{x}_{0} \rightarrow \mathbf{x}_{1}$ on:

- partitive unitary exergy cost of products (Eq. 2.14),

- $(M F)$ - direct exergy losses (Eq. 2.8),

- $\quad(D F)$ - induced exergy losses (Eq. 2.11),

what is crucial (due to Eq. 2.13) for the exact detection of causes and locations responsible for generation of exergy losses in all components of the system. If the energy analysis is able to answer only the question "How much?", the advanced exergy analysis based on $(M F)$ and $(D F)$ can answer additionally the questions "Why? And where the reasons are located?". To determine $(M F)$ and $(D F)$, the knowledge on partitive unitary exergy consumption indices $\kappa_{j-i}$ defined by Eq. 2.7 is fundamental. These indices can be determined making use of Fuel - Product table F-P. Structure of F-P table is presented in Tab. 1.

For the production system including $n$ components, the size of $\mathbf{F}-\mathbf{P}$ table is equal to $[n+1 ; n+1]$. Indices $i=1 ; \ldots ; n$ and $j=1 ; \ldots ; n$ concern components inside the balance boundary of analysed system. Index $i=0$ or $j=0$ concerns flows from the environment into the system boundary or outputs of the system. Particular rows of the F-P table present the distribution of component's products between other components of the system or products representing final products for external consumers. In Tab. 1 , green frame presents the distribution of product between other components inside the system $B_{i 1} ; \ldots ; B_{i n}$ and transferred outside balance boundary $B_{i 0}$ as final product. Red frame presents the origin of $j$-th component's fuel with allocation between internal components of the system $B_{1 j} ; \ldots ; B_{n j}$ and environment $B_{0 j}$.

Table 1. Structure of Fuel - Product (F-P)

\begin{tabular}{|c|c|c|c|c|c|c|c|}
\cline { 2 - 8 } \multicolumn{1}{c|}{} & \multicolumn{7}{c|}{ Fuel $\mathbf{F}$} \\
\hline Product $\mathbf{P}$ & $F_{0}$ & $F_{1}$ & $F_{2}$ & $\ldots$ & $F_{j}$ & $\ldots$ & $F_{n}$ \\
\hline$P_{0}$ & $B_{00}$ & $B_{01}$ & $B_{02}$ & $\ldots$ & $B_{0 j}$ & $\ldots$ & $B_{0 n}$ \\
\hline$P_{1}$ & $B_{10}$ & $B_{11}$ & $B_{12}$ & $\ldots$ & $B_{1 j}$ & $\ldots$ & $B_{1 n}$ \\
\hline$P_{2}$ & $B_{20}$ & $B_{21}$ & $B_{22}$ & $\ldots$ & $B_{2 j}$ & $\ldots$ & $B_{2 n}$ \\
\hline$\ldots$ & $\ldots$ & $\ldots$ & $\ldots$ & $\ldots$ & $\ldots$ & $\ldots$ & $\ldots$ \\
\hline$P_{i}$ & $B_{i 0}$ & $B_{i 1}$ & $B_{i 2}$ & $\ldots$ & $B_{i j}$ & $\ldots$ & $B_{\text {in }}$ \\
\hline$\ldots$ & $\ldots$ & $\ldots$ & $\ldots$ & $\ldots$ & $\ldots$ & $\ldots$ & $\ldots$ \\
\hline$P_{n}$ & $B_{n 0}$ & $B_{n 1}$ & $B_{n 2}$ & $\ldots$ & $B_{n j}$ & $\ldots$ & $B_{n n}$ \\
\hline
\end{tabular}




\subsection{Matrix algorithm for determination of extrinsic exergy losses}

In the procedure of exergy diagnostics, for the determination of induced exergy losses $(D F)$, an auxiliary matrix $\Pi$ is introduced $[4-6,8]$ :

$$
\boldsymbol{\Pi}=\left(\mathbf{U}_{\boldsymbol{D}}-\langle\mathbf{K P}\rangle\right)^{-\mathbf{1}}
$$

$\mathbf{U}_{\boldsymbol{D}} \quad$ unit matrix,

$\langle\mathbf{K P}\rangle$ square matrix including indices of unitary partitive exergy consumption $\kappa_{j-i}$, defined by Eq. 2.7 and determined basing on F-P table.

Additionally, a matrix including differences of indices of unitary exergy consumption $\kappa_{j-i}$ between operational state $\mathbf{x}_{\mathbf{1}}$ and assumed reference state $\mathbf{x}_{\mathbf{0}}$ needs to be determined:

$$
\Delta K P=K P\left(x_{1}\right)-K P\left(x_{0}\right)
$$

KP square matrix including indices of unitary partitive exergy consumption $\kappa_{j-i}\left(\right.$ for state $\mathbf{x}_{\mathbf{1}}$ or $\left.\mathbf{x}_{\mathbf{0}}\right)$.

A matrix including irreversibility coefficients $\phi_{i, j}$, necessary for the decomposition of exergy cost due to Eq. 2.14 can be calculated as [4-6,8]:

$$
\mathbf{I}=\left(\mathbf{K}_{\boldsymbol{D}}-\mathbf{U}_{\boldsymbol{D}}\right) \cdot \boldsymbol{\Pi}
$$

$\mathbf{K}_{\boldsymbol{D}}$ diagonal matrix including coefficients of unitary exergy consumption $k_{i}$ in particular components of the system.

A matrix including partitive disfunction coeficients $(D F)_{j i}$ for system components is calculated as:

$$
\mathrm{DF}=\left[\mathbf{I}\left(\mathbf{x}_{1}\right) \cdot \Delta \mathrm{KP}\right] \cdot \mathbf{P}_{\mathbf{0}}\left(\mathbf{x}_{\mathbf{0}}\right)
$$

$\mathbf{I}\left(\mathbf{x}_{1}\right)$ matrix of irreversibility coefficients $\phi_{i, j}$, determined for operational state $\mathbf{x}_{1}$, using Eq. 3.3,

$\mathbf{P}_{\mathbf{0}}\left(\mathbf{x}_{\mathbf{0}}\right)$ vector including exergy of products generated in particular components of the system determined for reference state $\mathbf{x}_{\mathbf{0}}$

\section{EXAMPLES - EXERGY DIAGNOSTICS OF A COMBINED CYCLE POWER PLANT}

The following subsections present two examples illustrating the application of theory of exergy cost and analysis of direct $(M F)$ and induced $(D F)$ exergy losses for diagnostics of a combined cycle gas turbine power plant. 


\subsection{Simplified system}

Fig. 3 presents a simplified scheme of a combined cycle gas turbine power plant. For the presented scheme, exergy diagnostics has been performed. Values of exergy streams for reference $\mathbf{x}_{\mathbf{0}}$ and operational $\mathbf{x}_{\mathbf{1}}$ state of the system are included in Table 2. Changes in exergy flows in particular points of the analysed system are the result of changing the isentropic efficiency of the steam turbine between reference and operational state from $\eta_{i T}\left(\mathbf{x}_{\mathbf{0}}\right)=0.88$ to $\eta_{i T}\left(\mathbf{x}_{\mathbf{1}}\right)=0.80$.

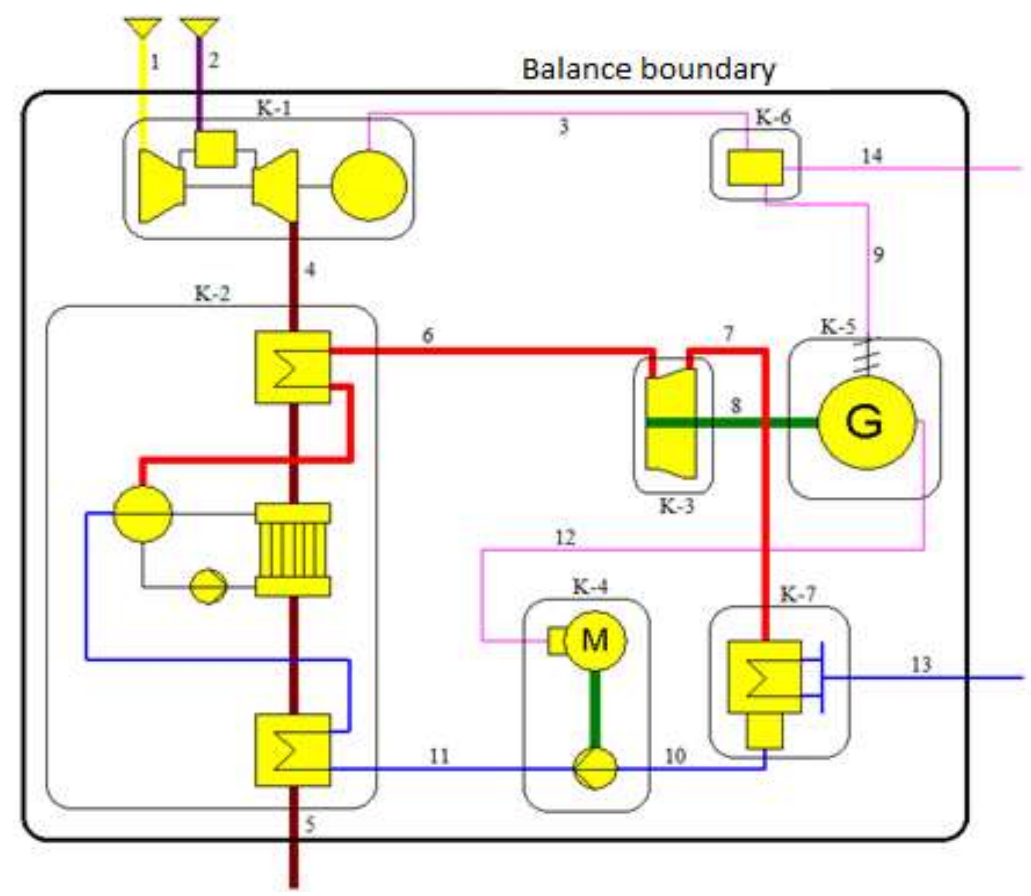

Fig. 3. Simplified combined cycle power plant [15]

Table 2. Exergy flows for reference $\boldsymbol{x}_{\mathbf{0}}$ and operational $\boldsymbol{x}_{\mathbf{1}}$ state

\begin{tabular}{|c|l|l|l|}
\hline \multirow{2}{*}{$i$} & \multicolumn{2}{|c|}{ Exergy flow } & \multicolumn{2}{|c|}{$\dot{B}, \mathrm{~kW}$} \\
\cline { 3 - 4 } & & \multicolumn{1}{|c|}{ State $\mathbf{x}_{\mathbf{0}}$} & \multicolumn{1}{|c|}{ State $\mathbf{x}_{\mathbf{1}}$} \\
\hline 1 & Air for gas turbine system & 0.00 & 0.00 \\
\hline 2 & Gaseous fuel for gas turbine system & 66950.73 & 68889.09 \\
\hline 3 & Electricity generated in gas turbine & 22585.48 & 23222.65 \\
\hline 4 & Flue gases entering heat recovery steam generator & 16882.03 & 17013.08 \\
\hline 5 & Flue gases leaving heat recovery steam generator & 3561.99 & 3602.59 \\
\hline 6 & Steam at the input of steam turbine & 11310.28 & 11814.34 \\
\hline 7 & Steam at the output of steam turbine & 315.60 & 463.15 \\
\hline 8 & Internal power of steam turbine & 9674.38 & 9109.48 \\
\hline
\end{tabular}




\begin{tabular}{|l|l|l|l|}
\hline 9 & Electricity from steam turbine generator & 9418.62 & 8781.45 \\
\hline 10 & Condensate & 1.20 & 1.36 \\
\hline 11 & Feeding water for the boiler & 80.49 & 85.01 \\
\hline 12 & Electricity supplying feeding water pump & 116.44 & 127.11 \\
\hline 13 & Heat from condenser & 314.40 & 461.80 \\
\hline 14 & Electricity for external consumers & 32004.10 & 32004.10 \\
\hline
\end{tabular}

Table 3 includes definitions of fuels $F$ (flows of exergy driving the component) and products $P$ (flows of useful exergy generated in components) for all components of power plant presented in Fig. 3.

Table 3. Fuel - Products definitions for analysed power plant

\begin{tabular}{|c|c|c|}
\hline Component & Fuel $(F)$ & Product $(P)$ \\
\hline K-1 & $B_{1}+B_{2}$ & $B_{3}+B_{4}$ \\
\hline K-2 & $B_{4}-B_{5}$ & $B_{6}-B_{11}$ \\
\hline K-3 & $B_{6}-B_{7}$ & $B_{8}$ \\
\hline K-4 & $B_{12}$ & $B_{11}-B_{10}$ \\
\hline K-6 & $B_{8}$ & $B_{9}+B_{12}$ \\
\hline K-7 & $B_{3}+B_{9}$ & $B_{14}$ \\
\hline & $B_{7}-B_{10}$ & $B_{13}$ \\
\hline
\end{tabular}

Making use of algorithm presented and discussed in previous section of the paper, exergy diagnostics of the system has been performed. Results of calculations of malfunctions $(M F)$ and disfunctions $(D F)$ are included in Tables 4 and 5.

Table 4. Results of calculations of direct exergy losses (MF), kW

\begin{tabular}{|c|c|c|c|c|c|c|c|c|c|}
\hline & & K-1 & $\mathrm{K}-2$ & K-3 & $\mathrm{K}-4$ & K-5 & K-6 & K-7 & \\
\hline$j$ & $i$ & 1 & 2 & 3 & 4 & 5 & 6 & 7 & \\
\hline 0 & Environment & 570.1 & 0.0 & 0.0 & 0.0 & 0.0 & 0.0 & 0.0 & \\
\hline 1 & K-1 & 0.0 & -480.7 & 0.0 & 0.0 & 0.0 & 637.2 & 0.0 & \\
\hline 2 & $\mathrm{~K}-2$ & 0.0 & 0.0 & 1052.1 & 0.0 & 0.0 & 0.0 & 146.3 & \\
\hline 3 & K-3 & 0.0 & 0.0 & 0.0 & 0.0 & 75,7 & 0.0 & 0.0 & \\
\hline 4 & K-4 & 0.0 & 0.0 & 8.3 & 0.0 & 0.0 & 0.0 & 1.1 & \\
\hline 5 & K-5 & 0.0 & 0.0 & 0.0 & 4.0 & 0.0 & -637.2 & 0.0 & \\
\hline 6 & K-6 & 0.0 & 0.0 & 0.0 & 0.0 & 0.0 & 0.0 & 0.0 & \\
\hline 7 & K-7 & 0.0 & 0.0 & 0.0 & 0.0 & 0.0 & 0.0 & 0.0 & $\sum$ \\
\hline & $(M F)$ & 570.1 & -480.7 & 1060.4 & 4.0 & 75.7 & 0.0 & 147.4 & 1377.0 \\
\hline
\end{tabular}

Table 5. Results of calculations of induced exergy losses (DF), $\mathrm{kW}$

\begin{tabular}{|c|c|c|c|c|c|c|c|c|c|}
\hline & & K-1 & $\mathrm{K}-2$ & K-3 & K-4 & K-5 & K-6 & K-7 & $(D F)$ \\
\hline$j$ & $i$ & 1 & 2 & 3 & 4 & 5 & 6 & 7 & \\
\hline 1 & K-1 & 0 & -423.30 & 1075.00 & 5.21 & 95.65 & -261.80 & 149.40 & 640.68 \\
\hline 2 & $\mathrm{~K}-2$ & 0 & 0 & 153.10 & 0.74 & 13.62 & -117.10 & 21.27 & 71.60 \\
\hline 3 & K-3 & 0 & 0 & 3.21 & 1.03 & 18.90 & -162.60 & 0.41 & -139.00 \\
\hline 4 & K-4 & 0 & 0 & 4.36 & 0.02 & 0.35 & -3.03 & 0.56 & 2.26 \\
\hline
\end{tabular}




\begin{tabular}{|r|r|r|r|r|r|r|r|r|r|}
5 & K-5 & 0 & 0 & 0.29 & 0.09 & 0.02 & -14.57 & 0.04 & -14.13 \\
\hline 6 & K-6 & 0 & 0 & 0 & 0 & 0 & 0 & 0 & 0 \\
\hline 7 & K-7 & 0 & 0 & 0 & 0 & 0 & 0 & 0 & 0 \\
\hline \multicolumn{10}{|c|}{} \\
\hline
\end{tabular}

Results of calculations of malfunctions and disfunctions are additionally sumarized in Fig. 4.

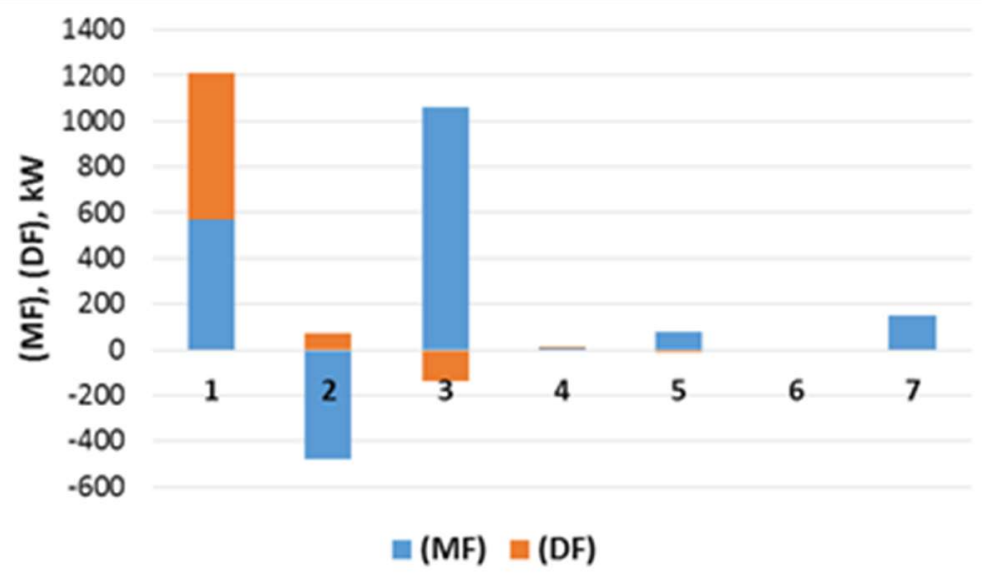

Fig. 4. Results of calculations (MF) i (DF) for analysed power plant

First of all, it should be underlined that the influence of changes in operational parameters on the change of total fuel consumption $\Delta F_{T}$ can be evaluated making use only of direct exergy analysis; these results are included in Table 2. Due to this analysis $\Delta F_{T}=B_{2}\left(\mathbf{x}_{\mathbf{1}}\right)-B_{2}\left(\mathbf{x}_{\mathbf{0}}\right)=1939 \mathrm{~kW}$. This direct analysis is however not able to recognize the real reasons and locations of generation of exergy losses. The detailed analysis of these effects is possible only by application of procedures to determine direct $(M F)$ and induced $(D F)$ exergy losses. In the presented example, the share of direct exergy losses is at the level $(M F) / \Delta F_{T}=$ $70 \%$, and induced losses reach the level of $(D F) / \Delta F_{T}=30 \%$. The highest direct exergy losses occur in the component in which the operational parametrs have been directly changed - internal efficiency of steam turbine (component K-3). Direct exergy losses in this component reach the level $(M F)_{3}=1060.4 \mathrm{~kW}$. However, these local losses induce the highest induced exergy losses in component $\mathrm{K}-1$, reaching the level of $(D F)_{1}=640.7 \mathrm{~kW}$. These induced losses represent the share in total fuel impact at the level $\Delta F_{T}=33 \%$. It confirms that for detailed detection of reasons and places of loses, direct exergy analysis is not sufficient and the presented advanced exergy tools - exergy diagnostics procedures - have to be applied. 


\subsection{Real system of a combined cycle gas turbine power plant}

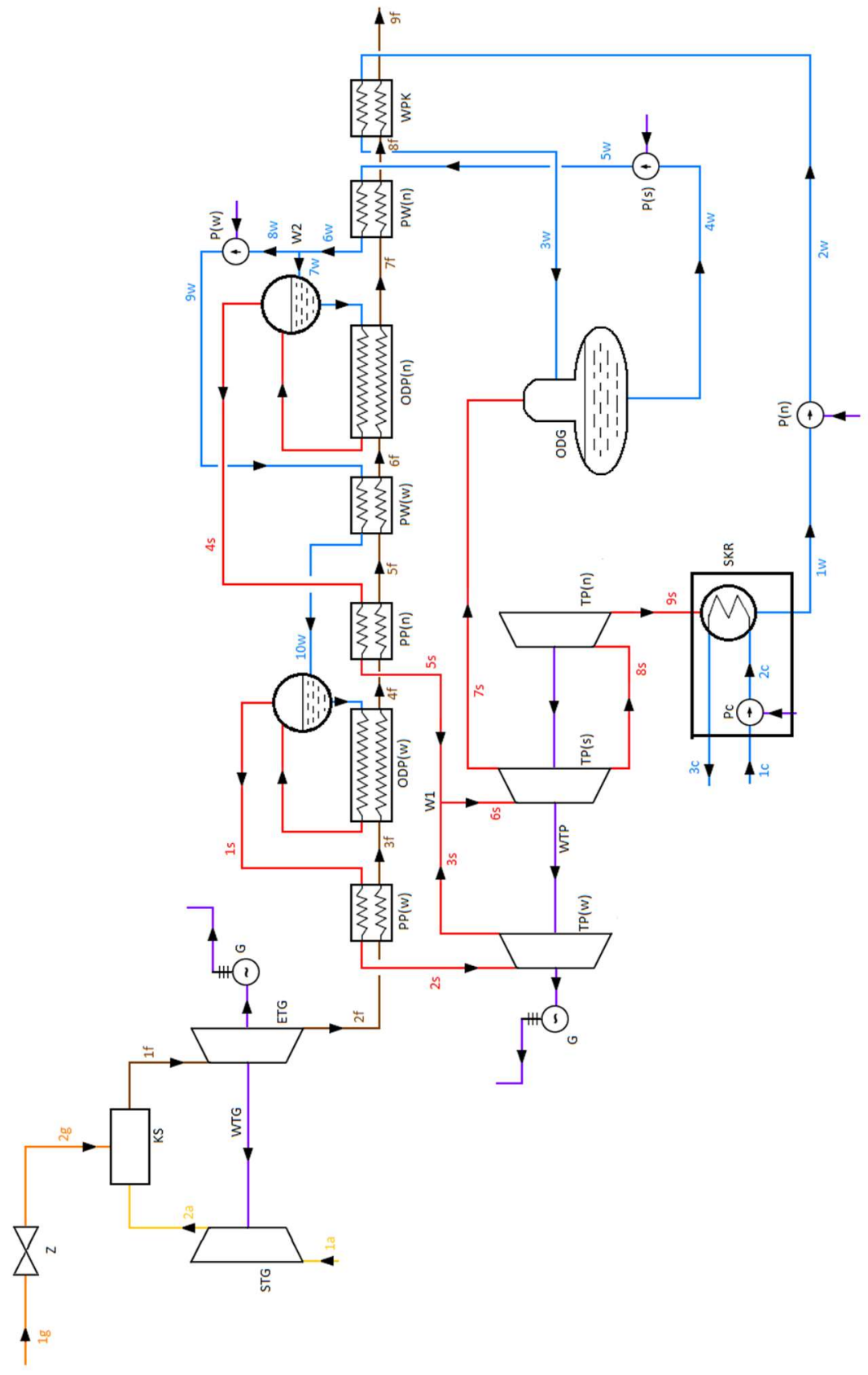

Fig. 5. Scheme of analysed gas-and-steam power plant 
Scheme of analysed combined cycle power plant is presented in Fig. 5. Gas turbine is fed with natural gas. Flue gases from the gas turbine are supplied to the heat recovery steam generator (HRSG). Steam is generated at two pressure levels. High pressure steam feeds the first stage of steam turbine.

After this stage it is mixed with low pressure steam and feeds the medium pressure turbine. The condensate is preheated using flue gases from last stages of recovery boiler. Net electric power of the system is $375 \mathrm{MW}$. The system comprises of 27 components and 49 flows of exergy. Definitions of fuels and products are summarized in Tab. 5.

Tab. 5. Definitions of fuel and product in components

\begin{tabular}{|c|c|c|c|}
\hline$i$ & Component & Fuel $(F)$ & Product $(P)$ \\
\hline 0 & Environment & $B_{9 f^{\prime}}+B_{3 c}+N_{\text {el netto }}$ & $B_{l g}+B_{l a}+B_{l c}$ \\
\hline 1 & Throttle - Z & $B_{\lg }$ & $B_{2 g}$ \\
\hline 2 & Combustion chamber - KS & $B_{2 g}$ & $B_{1 f-}-B_{2 a}$ \\
\hline 3 & Gas compressor - STG & $N_{i S T G}$ & $B_{2 a}-B_{1 a}$ \\
\hline 4 & Gas expander - ETG & $B_{1 f-}-B_{2 f}$ & $N_{i E T G}$ \\
\hline 5 & High pressure superheater - $\mathrm{PP}(\mathrm{w})$ & $B_{2 f-}-B_{3 f}$ & $B_{2 s}-B_{1 s}$ \\
\hline 6 & High pressure evaporator - ODP(w) & $B_{3 f}-B_{4 f}$ & $B_{1 s}-B_{10 w}$ \\
\hline 7 & Low pressure superheater - $\mathrm{PP}(\mathrm{n})$ & $B_{4 f-}-B_{5 f}$ & $B_{5 s}-B_{4 s}$ \\
\hline 8 & High pressure economizer - $\mathrm{PW}(\mathrm{w})$ & $B_{5 f}-B_{6 f}$ & $B_{10 w}-B 9_{w}$ \\
\hline 9 & Low pressure evaporator - ODP(n) & $B_{6 f-}-B_{7 f}$ & $B_{4 s}-B_{7 w}$ \\
\hline 10 & Flow splitter - W2 & $B_{6 w}$ & $B_{7 w}+B_{8 w}$ \\
\hline 11 & Low pressure economizer - PW(n) & $B_{7 f-B_{8 f}}$ & $B_{6 w}-B_{5 w}$ \\
\hline 12 & Condensate preheater - WPK & $B_{8 f-}-B_{9 f}$ & $B_{3 w}-B_{2 w}$ \\
\hline 13 & High pressure steam turbine - TP(w) & $B_{2 s}-B_{3 s}$ & $N_{i T P(w)}$ \\
\hline 14 & Flow mixer - W1 & $B_{3 s}+B_{5 s}$ & $B_{6 s}$ \\
\hline 15 & $\begin{array}{l}\text { Medium pressure steam turbine - } \\
\text { TP(s) }\end{array}$ & $B_{6 s}-B_{7 s}-B_{8 s}$ & $N_{i} T P(s)$ \\
\hline 16 & Low pressure steam turbine - TP(n) & $B 8 s-B 9_{s}$ & $N_{i T P(n)}$ \\
\hline 17 & Deaerator - ODG & $B 7_{s}$ & $B_{4 w}-B_{3 w}$ \\
\hline 18 & Low pressure pump - $\mathrm{P}(\mathrm{n})$ & $N_{i P(n)}$ & $B_{2 w}-B_{I w}$ \\
\hline 19 & Medium pressure pump - $\mathrm{P}(\mathrm{s})$ & $N_{i P(s)}$ & $B_{5 w}-B_{4 w}$ \\
\hline 20 & High pressure pump - $\mathrm{P}(\mathrm{w})$ & $N_{i P(w)}$ & $B_{9 w}-B_{8 w}$ \\
\hline 21 & Shaft of gas turbine - WTG & $N_{i E T G-N} N_{i S T G}$ & $N_{m T G}$ \\
\hline 22 & Shaft of steam turbine - WTP & $N_{i T P(w)}+N_{i T P(s)}+N_{i T P(n)}$ & $N_{m T P}$ \\
\hline 23 & Shafts of pumps - WP & $N_{m P}$ & $N_{i P(n)}+N_{i P(s)}+N_{i P(w)}+N_{i P c}$ \\
\hline 24 & Electric motors - S & $N_{e l P}$ & $N_{m P}$ \\
\hline 25 & Generator - G & $N_{m T P}+N_{m T G}$ & $N_{\text {el P }}+N_{\text {el netto }}$ \\
\hline 26 & Stack - KO & $B_{9 f}$ & $B_{9 f^{\prime}}$ \\
\hline 27 & Steam condenser - SKR & $B_{9_{s}}-B_{1 w}+N_{i P_{c}}$ & $B_{3 c}-B_{l c}$ \\
\hline
\end{tabular}

Fig. 6 presents exergetic costs of electricity prouced in gas turbine, steam turbine and total electricity. Exergetic costs have been calculated according to Eq. 2.14. Inverse of total exergetic cost is equal to exergetic efficiency of a given 
component. In the analysed example, total exergetic efficiency of electricity generation equals to $58.83 \%$.

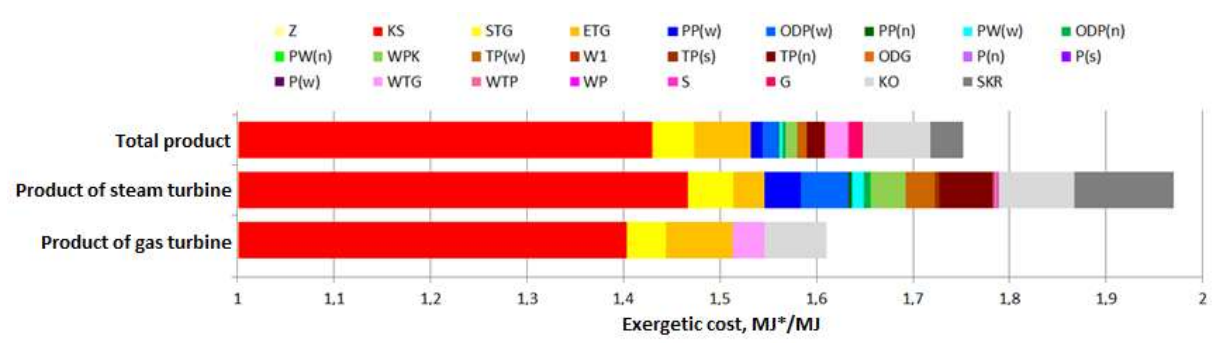

Fig. 6. Partitive exergetic costs of chosen products

Losses of exergy occuring during the combustion proces (red color) have the highest influence on the efficiency of electricity generation. Other important factors are: irreversibilities in gas compressor and expander (yellow and orange color), exergy losses during heat transfer in the HRSG (shades of blue and green) and incomplete utilization of heat of flue gases (light grey).

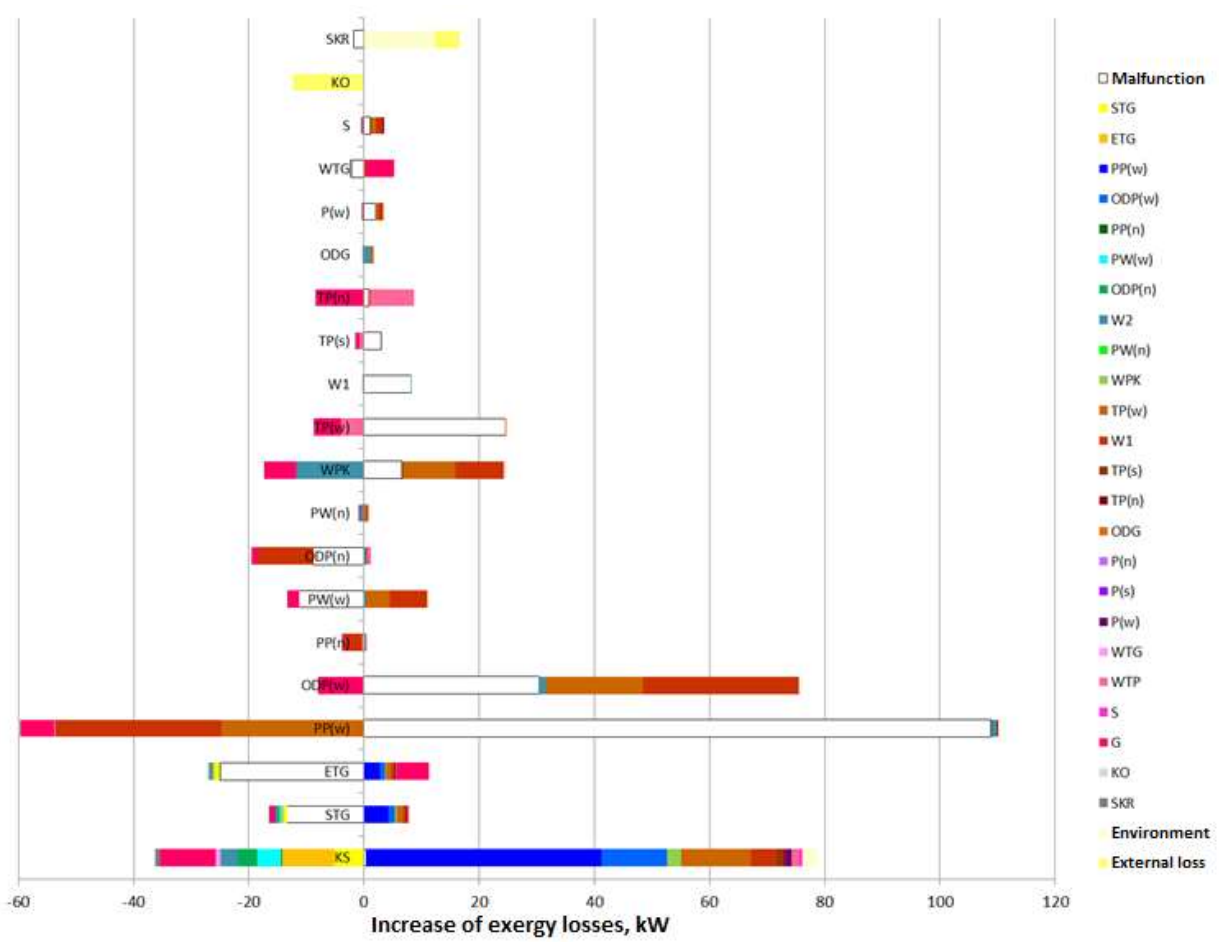

Fig. 7. Malfunctions and disfunctions of chosen components 
Operation of the system with changed parameters ("operational state") has also been analysed. In the operational state, conditions of heat transfer in high pressure superheater have been worsened. In the reference state the temperature of live steam is $565^{\circ} \mathrm{C}$, and in operational state $560^{\circ} \mathrm{C}$. Net electric power of the system is constant and equals to $375 \mathrm{MW}$. Calculations of malfunctions and disfunctions have been performed and compared to the results of simple energy analysis.

Energy analysis exposes an increase of electric and mechanical losses by $6 \mathrm{~kW}$, a decrease of external loss of heat in flue gases by $68 \mathrm{~kW}$ and an increase of external heat loss in the condenser by $218 \mathrm{~kW}$, which in total causes the stream of energy of fuel fed to the system to increase by $157 \mathrm{~kW}$. Exergy analysis allows to identify why and where these losses actually occur. Fig. 7 shows malfunctions and disfunctions of chosen components of the system.

Operation conditions have been primarily worsened in the high pressure superheater, which is reflected by high value of malfunction in this component. The worsening causes also an increase of losses in the steam turbine, which lowers it power. The missing power needs to be covered by the gas turbine, hence the exergy balance of combustion chamber is characterized by a high share of disfunction originating from superheater and steam turbine. The highest increases of losses occurred in the high pressure evaporator $\operatorname{ODP}(\mathrm{w})(68.3 \mathrm{~kW})$, the high pressure superheater $\mathrm{PP}(\mathrm{w})(51 \mathrm{~kW})$ and the combustion chamber KS $(42.5 \mathrm{~kW})$. However, exergy losses decreased in the low pressure evaporator $\operatorname{ODP}(\mathrm{n})$ $(-18.1 \mathrm{~kW})$ and the gas expander ETG $(-15.6 \mathrm{~kW})$.

\section{CONCLUSIONS}

The article presented an algorithm of exergetic diagnostics which allows to examine the influence of changes of working conditions of the system on partitive exergetic costs and intrinsic and extrinsic exergy losses. A practical implementation of this algorithm has been presented using examples of a simplified and real combined cycle gas turbine power plants. The results of calculations confirm the purposefulness of applying exergy methods and their potential in terms of diagnostics of energy systems.

Analysis of partitive exergetic costs allows to examine how the exergetic cost of a given component is influenced by exergy losses generated in other components of the system. As for the analysis of direct and induced exergy losses, it is possible to identify how the losses generated in one component (due to a change in operational parameters) affect the generation of losses in other components. As an example, worsened isentropic efficiency of a steam turbine causes more exergy to be destructed in the turbine, but at the same time it forces additional exergy losses in the gas turbine. These losses can be decreased by improving the efficiency of the steam turbine, not the gas turbine. Analysis of induced losses is 
not possible using only classic methods of thermal diagnostics. Therefore, applying exergy diagnostics greatly broadens the possibilities in tems of control of operation and diagnostics of energy systems.

\section{REFERENCES}

1. Kopaliński, W 1970. Stownik wyrazów obcych i zwrotów obcojęzycznych. Warszawa: Wiedza Powszechna.

2. Rusinowski, H 2010. Diagnostyka cieplna eksploatacji $w$ energetyce. Katowice-Gliwice: Wydawnictwo Polskiej Akademii Nauk - Oddział w Katowicach.

3. Kościelny, JM 2001. Diagnostyka zautomatyzowanych procesów przemystowych. Warszawa: Akademicka Oficyna Wydawnicza EXIT.

4. Torres, C and Valero, A 2014. Thermoeconomic Analysis. CIRCE University of Zaragoza. Access [20.05.2014] www.exergoecology.com.

5. Torres, C, Valero, A, Serra, L and Royo, J 2002. Structural theory and thermoeconomic diagnosis. Part I: on malfunction and dysfunction analysis. Energy Conversion and Management 43, 1503-1518.

6. Torres, C 2006. Symbolic Thermoeconomic Analysis of Energy Systems. Oxford: EOLSS Publishers.

7. Correas, L 2007. On the thermoeconomic approach to the diagnosis of energy system malfunctions. Suitability to real-time monitoring. International Journal of Thermodynamics 7, 85-94.

8. Valero, A, Correas, L and Serra, L 1999. On-line thermoeconomic diagnosis of thermal power plants. Thermodynamic Optimization of Complex Energy Systems. Bejan, A, Mamut, A, editors. New York: Kluwer Academic Publishers, 117-136.

9. Valero, A, Correas, L, Zaleta, A, Lazzaretto, A, Verda, V, Reini, M and Rangel, V 2004. On the thermoeconomic approach to the diagnosis of energy system malfunctions. Part 1: the TADEUS problem. Energy 29, 1875-1887.

10. Valero, A, Correas, L, Zaleta, A, Lazzaretto, A, Verda, V, Reini, M and Rangel, V 2004. On the thermoeconomic approach to the diagnosis of energy system malfunctions. Part 2. Malfunction definitions and assessment. Energy 29, 1889-1907.

11. Rusinowski, H and Stanek, W 2007. Neural modelling of steam boilers. Energy Conversion and Management 48, 2802-2809.

12. Stanek, W and Rusinowski, H 2008. Application of empirical modellng for construction of auxiliary models of steam boiler. Archives of Thermodynamics 29, 165-176.

13. Rusinowski, H and Stanek, W 2010. Hybrid model of steam boiler. Energy 35, 1107-1113. 
14. Stanek, W, Rusinowski, H and Budnik, M 2009. Energy and exergy evaluation of a boiler's operation with the application of a hybrid model. 22nd International Conference ECOS'09, 31 Aug - 3 Sep, Foz do Iguaçu, Paraná, Brazil.

15. Lomania, K 2015. Analiza termo-ekonomiczna elektrociepłowni gazowoparowej [MSc thesis written under supervision of W. Stanek]. Gliwice: Instytut Techniki Cieplnej, Politechnika Śląska.

\section{DIAGNOSTYKA EGZERGETYCZNA ELEKTROWNI GAZOWO-PAROWEJ}

\section{Streszczenie}

W praktyce do oceny efektywności termodynamicznej działania elektrowni lub elektrociepłowni stosuje się narzędzia tak zwanej diagnostyki cieplnej opartej na bilansowaniu energetycznym. Analiza energetyczna nadaje się jednak wyłącznie do oceny ilościowej oraz porównywania podobnych technologii energetycznych. Dla prawidłowej oceny miejsc i przyczyn powstawania strat $\mathrm{w}$ systemach energetycznych konieczne jest zastosowanie analizy egzergetycznej. W artykule zaprezentowano zasady diagnostyki egzergetycznej, znacznie poszerzającej potencjał klasycznej diagnostyki cieplnej wraz z przykładem obliczeniowym dotyczącym elektrowni gazowo-parowej. Diagnostyka egzergetyczna jest techniką $\mathrm{z}$ zakresu zaawansowanej analizy egzegetycznej, pozwalającą na szczegółową detekcję przyczyn generowania strat w komponentach $\mathrm{z}$ uwzględnieniem tak zwanych przyczyn wewnątrzpochodnych i zewnątrzpochodnych. Procedury diagnostyki egzergetycznej, w połączeniu $\mathrm{z}$ technikami modelowania matematycznego, pozwalają na poszerzoną kontrolę eksploatacji procesów i systemów produkcyjnych. Ponadto umożliwiają one dekompozycję kosztu egzergetycznego pomiędzy składowe wynikające z wzajemnych powiązań pomiędzy komponentami systemu. Zaprezentowany przykład obliczeniowy dotyczący elektrowni gazowo-parowej prezentuje potencjał diagnostyki egzergetycznej w zakresie lokalizacji strat egzergii i wyjaśnia przyczyny zwiększonego zużycia zasobów zasilających system poprzez porównanie dwóch stanów: referencyjnego oraz dowolnego stanu eksploatacyjnego systemu.

Słowa kluczowe: diagnostyka egzergetyczna, elektrownia gazowo-parowa, model matematyczny

Editor received the manuscript: 07.01.2019 